\title{
Possible Cytotoxic Activity of Annona muricata Leaves in Huh-7 Human Liver Cancer Cells
}

\author{
Banerjee $A^{1}$, Sengupta $\mathbf{A}^{1}$, Maji $\mathbf{B}^{1}$, Nandi $\mathbf{A}^{2}$, Pal $\mathbf{S}^{3}$ and Mukherjee $\mathbf{S}^{1 *}$ \\ ${ }^{1}$ Department of Physiology, Serampore College, West Bengal, India \\ ${ }^{2}$ Department of Physiology, University of Calcutta, West Bengal, India \\ ${ }^{3}$ Department of Physiology, YS Palpara Mahavidyalaya, West Bengal, India
}

\begin{abstract}
Background: Hepatocellular carcinoma (HCC) is the fifth most basic type of disease on the planet. Regardless of such a variety of choices for HCC treatment, the cure rate for patients is generally low especially among patients who are ineligible for surgical or percutaneous methods. HCC is generally viewed as a chemotherapy-safe malady. These disadvantages require the proceeded with scan for novel $\mathrm{HCC}$ treatments. The plant Annona muricata has been accounted for to have acetogenins as major phytoconstitutent which are in charge of number of exercises and one of them is anticancer and antiproliferative impacts against different tumors. The present study was intended to assess the anticancer potential of aqueous extract of Annona muricata leaves (AEAML) against Huh-7 human liver cancer cells.
\end{abstract}

Methods: The cytotoxic impact of AEAML on Huh-7 cells was tried by MTT examine. Cells were tested with 0.5 , 1.0 , and $1.5 \mathrm{mg} / \mathrm{ml}$ concentrate of AEAML for 24 hours. The apoptotic genes Bax and Bcl-2 expression were assessed by utilizing RT-PCR, and after that decide the protein expression of caspase 3 and 9 by western blot. Comet assay was performed in Huh-7 cells for the DNA damage and apoptosis.

Results: Cell viability investigation uncovered the cytotoxic impact of AEAML on Huh-7cell line. RT-PCR of anti- apoptotic Bcl-2 and pro-apoptotic Bax demonstrated that there is down and up control, individually, of these two qualities with an unfriendly impact. Additionally, AEAML treatment set off the actuation of caspase- 9 followed by caspase- 3 protein expression. Also, AEAML incited DNA damage and apoptosis on Huh- 7 cells as uncovered by Comet tail length.

Conclusion: Annona muricata has antiproliferative and cytotoxic impacts on Huh-7 cells, conceivably through apoptosis induction.

Keywords: Annona muricata; Hepatocellular carcinoma; Huh-7; Cytotoxicity; Apoptosis

\section{Introduction}

In the present time, malignancy is one of the most serious diseases after the deadly heart disease. There are numerous different types of cancer such as cervical cancer, skin cancer, leukemia, lung cancer, liver cancer, breast cancer, prostate cancer, oral cancer and so on. As indicated by World Health Organization (WHO), cancer represents 7 million deaths for every year [1].

Liver cancer in male is the second most frequent cause of cancer death and the sixth leading cause of cancer death in female. Primary malignancy of the liver occurs predominantly in patients associated with chronic liver disease and cirrhosis. The cells of origin are believed to be the hepatic stem cells, although this remains the subject of investigation [2]. The typical features of the disease associated with abdominal mass, abdominal pain, emesis, anemia, back pain, jaundice, itching, weight loss and fever. Surgical elimination is often considered as a treatment of choice in patients with non-cirrhotic livers. As liver is often detected in late stage, less than $30-40 \%$ of patients only are eligible for surgery and transplant. Percutaneous removal is just the non-surgical system that can offer cure. Liver is not tolerant to radiation and in this way radiotherapy is not in the slightest degree a possibility for hepatocellular carcinoma quiet. Globally, the rates of death are higher in males than in females. East and South-East Asia and Middle and Western Africa have higher number of liver cancer cases, whereas South-Central and Western Asia, as well as Northern and Eastern Europe have comparatively lower number of such cases. Among primary liver cancers, hepatocellular carcinoma (HCC) speaks to the major histological subtype, accounting for $70 \%$ to $85 \%$ of the total liver cancer burden worldwide. Cholangiocarcinomas that arise primarily from the epithelial lining of the bile duct (intra and extra hepatic bile duct) are relatively rare, but high incidence rates are found in Thailand and other parts of Eastern Asia largely due to the elevated prevalence of liver fluke infection [3]. Cirrhosis due to either hepatitis B, hepatitis C, or alcohol is the significant reason of hepatocellular carcinoma.

Home grown pharmaceutical goes about as the delegate of the most critical fields of customary medication, everywhere throughout the World. The review on the restorative plants is basic to advance the best possible utilization of natural prescription with a specific end goal to decide their potential as a hotspot for the new medications. As per WHO more noteworthy than $80 \%$ of the aggregate total populace relies on upon the conventional drugs with a specific end goal to fulfill their essential medicinal service's needs. Annona muricata, commonly known as graviola or soursop, belongs to Annonaceae family. It is a native of North America but rarely grown in India. Traditionally, the leaves of Annona muricata are used for headaches, insomnia, cystitis, liver problems, diabetes, and hypertension and as an anti-

*Corresponding author: Dr. Sandip Mukherjee, Assistant Professor, Serampore College, Department of Physiology, Hooghly-712201, West Bengal, India, Tel: +919830632675; E-mail: sm_kdc@yahoo.co.in

Received February 06, 2017; Accepted February 22, 2017; Published February 28, 2017

Citation: Banerjee A, Sengupta A, Maji B, Nandi A, Pal S, et al. (2017) Possible Cytotoxic Activity of Annona muricata Leaves in Huh-7 Human Liver Cancer Cells. Hepatol Pancreat Sci 1: 104.

Copyright: ( 2017 Banerjee A, et al. This is an open-access article distributed under the terms of the Creative Commons Attribution License, which permits unrestricted use, distribution, and reproduction in any medium, provided the original author and source are credited. 
inflammatory, antispasmodic and antidysenteric agent. These effects are thought to be due to presence of terpenoid, steroid, flavonoids, cardiac glycoside, tannin, phenol, alkaloid, and reducing sugar in the ethanolic extract of $A$. muricata leaf as uncovered by its phytochemical screening. Epidemiologic study presented that breast cancer patients had a significantly lower mortality rate when treated with cardiac glycosides contrasted with their untreated counterpart. Likewise, their cancer cells had more benign characteristics than those from patients without cardiac glycoside treatment. Phenol was determined to be quantitatively present in the highest amount [4]. Dietary polyphenols interfere with signal transduction pathways related to the carcinogenesis process, thereby acting as chemopreventive agents. They include the suppression of NF- $\kappa \mathrm{B}$ and activating protein (AP-1) activation, inhibition of the mitogen-activated proteins (MAPKs), protein kinasesand growth-factor receptor mediated pathways, cell cycle arrest, induction of apoptosis, anti-oxidant and anti-inflammatory effects, and suppression of angiogenesis [5]. The plant has been accounted for to possess acetogenins as major phytoconstitutents which are responsible for number of activities such as antitumor, immunomodulator, antispasmodic, antimalarial, pesticidal, antiparasitic, antibacterial, antifungal and antihelmintic activity. The annonaceous acetogenins are selectively toxic to cancer cells, including multi-drug-resistant cancer cell lines [6].

Previous study showed that the ethanol extract of leaves of $A$. muricata causes apoptosis of liver cancer cells in vitro through ER stress pathway [7]. Ethanolic extracts of A. muricata leaves demonstrated chemopreventive effects in a model of skin papilloma genesis, with complete inhibition of the tumour development and significant increase in latent period [8]

A. muricata leaves indicated most grounded cytotoxic action against MCF-7 bosom disease cell line [9] and it induced apoptosis in A549 cells through mitochondrial-mediated pathway involving NF- $\kappa B$ [10]. A. muricata hexane and commercialized extracts incited mellow cytotoxicity in pancreatic cancer cell Capan-1, HeLa cervical cancer cells, Vero cell line $[11,12]$. Ethanol extract of leaves of $A$. muricata has cytotoxic activity in T47D breast cancer cell lines and can initiate apoptosis. Ethyl acetate fraction has the best potency of cytotoxic among other fractions against T47D breast cancer cell lines [13]. Aqueous leaf extract of $A$. muricata have antiproliferative activity of on the prostate, $\mathrm{BPH}-1$ cells, and some target genes and reduces prostate size, possibly through apoptosis [14].

In this back drop, the present study was proposed to evaluate the apoptosis induction potential of A.muricata leaf extract in Huh-7 HCC cells and also to find its possible mechanism of action. So, the present study may be our initiation for the future drug against hepatocellular carcinoma.

\section{Materials and Methods}

\section{Cell cultures}

The Huh-7 cells were grown in Dulbecco's Modified Eagle medium (Gibco, USA) supplemented with 10\% of fetal bovine serum, $100 \mathrm{IU} /$ $\mathrm{ml}$ penicillin and $100 \mu \mathrm{g} / \mathrm{ml}$ of streptomycin (Gibco, USA) using 25 $\mathrm{cm}^{2}$ flasks (Nunc, Denmark), in a $\mathrm{CO}_{2}$ incubator (Heal Force) at $37^{\circ} \mathrm{C}$.

\section{Preparation of plant extract}

The leaves of Annona muricata were gathered from Kerala and authenticated by Department of Botany, Serampore College. Leaves were washed by rubbing the surface gently under running water. They were later sun-dried for three days. Leaves were processed and drenched by the extent of $1 \mathrm{~kg}$ of the processed substance absorbed $4000 \mathrm{~mL}$ of water for 24 hours. The mixture was then boiled for 1 hour and filtered through fine linen gauze. The marc was then soaked with another 3000 $\mathrm{mL}$ of water for another 24 hours and filtered. Then filtered solutions were then pooled and freeze-dried. The yield from $1 \mathrm{~kg}$ of ground substance was $25.2 \mathrm{~g}$ [14].

\section{MTT assay}

Trypan blue was utilized to determine the viability of cells. Exponentially growing cells were harvested, counted by hemocytometer and diluted with medium, yielding a concentration of $1 \times 10^{5} \mathrm{cells} / \mathrm{ml}$. From this cell suspension, $100 \mu \mathrm{l}$ was pipetted into 96-well microtiter plates (Nunc, Denmark) and incubated for 24 hours in a $5 \% \mathrm{CO}_{2}$ incubator (Heal Force) at $37^{\circ} \mathrm{C}$. Cells were then treated with $0.5,1.0$ and $1.5 \mathrm{mg} / \mathrm{ml}$ extract (in phosphate-buffered saline). After adding the extract samples, new medium was added to make the final volume of $200 \mu \mathrm{l}$ per well. The plate was then incubated in the $5 \% \mathrm{CO}_{2}$ incubator at $37^{\circ} \mathrm{C}$ for 24 hours. At the end of treatment time, the medium was replaced by $100 \mu \mathrm{MTT}$ (Sigma, St Louis, MO) per well and incubated for another 4 hours at $37^{\circ} \mathrm{C}$. The reaction was stopped by adding $100 \mu \mathrm{DMSO}$, AR grade (Sigma) to each well to dissolve the purple-blue MTT formazan precipitate. Finally, the absorbance was read with the ELISA reader (LX800) and calculates the percentage of viable and non-viable cells.

\section{RNA extraction and reverse transcriptase polymerase chain reaction (RT-PCR)}

Total RNA was extracted using TriZol reagent (Invitrogen, Carlsbad, CA). Oligo (dT)-primed RNA $(1 \mu \mathrm{g})$ was reverse transcribed using the Super Script II transcriptase kit (RR047A, Takara, Shiga, Japan) according to the manufacturer's instructions. cDNA obtained was amplified by PCR with Taq DNA polymerase (Fermentas, Burlington, Canada). The presence of possible target genes Bax and $\mathrm{Bcl}-2$ were determined using the obtained cDNA and glyceraldehyde3-phosphate dehydrogenase (GAPDH) as the internal control (Table 1). The PCR products were then resolved on $1 \%$ agarose gel. The bands were identified based on the product size using DNA ladder. Gel images were analyzed by scanning densitometry (Image J, NIH) and values were normalized to quantity of GAPDH and presented as percentage mRNA relative to control.

\section{Western blot analysis}

Protein was extracted by Minute TM Total Protein Extraction Kit (For Animal Cultured Cells and Tissues). To detect changes in apoptosis-related proteins (Caspase 3 and Caspase 9), Huh 7 cells $(1 \times$ $10^{7}$ cells) seeded on a $10 \mathrm{~cm}^{2}$ dish were treated with Annona muricata at different concentrations. The cells were harvested and lysed using a lysis buffer, and the protein concentrations of the cell lysates were quantified with a protein assay kit. The equivalent of $20-50 \mu \mathrm{g}$ of total proteins were separated on $10 \%$ SDS-PAGE, then electroblotted on PVDF membrane; the membranes were blocked with $10 \%$ non-fat dry milk in TBS-T overnight at $4^{\circ} \mathrm{C}$, then incubated with primary antibodies against with caspase 3 and caspase $9, \beta$-actin $(1: 1000)$ for $1.5 \mathrm{~h}$ at room temperature. After a wash with TBS-T, membranes were incubated with HRP-conjugated secondary antibodies (dilution 1:1,000) for $1 \mathrm{~h}$ at room temperature. Finally, the protein-antibody complexes were visualized by chemiluminescence (ECL system, Pierce). Protein expression was normalized to that of $\beta$-actin.

\section{Comet assay}

0.025\% Trypsin was added to the cells after removing media. At 
Citation: Banerjee A, Sengupta A, Maji B, Nandi A, Pal S, et al. (2017) Possible Cytotoxic Activity of Annona muricata Leaves in Huh-7 Human Liver Cancer Cells. Hepatol Pancreat Sci 1: 104.

Page 3 of 6

\begin{tabular}{|c|c|c|}
\hline Primer & Forward primer & Reverse primer \\
\hline GAPDH & 5'-AACGACCCCTTCATTGAC-3' & 5'-TCCACGACATACTCAGCAC-3' \\
\hline Bcl2 & 5-GTACCTGAACCGGCATCTG-3 & 5-GGGGCCATATAGTTCCACAA-3 \\
\hline Bax & 5-GACCAGCATGACAGATTTCTAC-3 & 5-CAAACTGAGACTAAGGCAGAA GATG-3 \\
\hline
\end{tabular}

Table 1: The sequences of primers used for amplification.

that time point, the cells were kept at $37^{\circ} \mathrm{C}$ for 5 minutes to detach cells. Clear window frosted microscopic slide was coated with $1 \%$ normal melting agarose. The well was punched at one side of the slide the aliquot of $10 \mu \mathrm{l}$ cell suspensions ( 10,000 cells in $10 \mu \mathrm{l}$ or less volume) was added and to this $20 \mu \mathrm{l}$ of lysis solution was added followed by another coat of $0.5 \%$ of low melting agarose at $37^{\circ} \mathrm{C}$. the slide was placed in moisture chamber for overnight. After lysis, the slide was immersed in the freshly prepared electrophoresis buffer $(10 \mathrm{mM}$ Tris, $0.08 \mathrm{mM}$ Boric acid, 0.5 M EDTA, pH 8.2) and electrophoresed for $1 \mathrm{~h}$ at $50 \mathrm{~V}$ after electrophoresis slide was dehydrated by immersing in absolute alcohol for 3-5 times. Then slide was stained with ethidium bromide followed by observation under trans-illuminator for comet formation and image was photographed and analyzed.

\section{Statistical analysis}

Data were expressed as Mean \pm SE. Kruskal-Wallis non parametric one-way analysis of variance (ANOVA) test was performed to find whether or not scores of different groups differ significantly and to test intergroup significant difference, Mann-Whitney $U$ multiple comparison tests was performed by using StatDirect Software (UK). Differences were considered significant if $\mathrm{P}<0.05$.

\section{Results}

The impacts of AEAML on the viability of Huh-7 cells were tested by the MTT assay. The outcomes uncovered that different concentrations of AEAML could potently restrain cell growth. MTT assay exhibited a significant dose dependent decrease in cell viability of Huh-7 cell line. Cell viability reduced from $100 \%$ to $74.3 \%, 58.3 \%$, and $28 \%$ as the dose of AEAML was increased from $0 \mathrm{mg} / \mathrm{ml}$ to $0.5(\mathrm{P}<0.05), 1.0(\mathrm{P}<0.01)$ to $1.5 \mathrm{mg} / \mathrm{ml}(\mathrm{P}<0.01)$, respectively pointing out to the fact that the cell morphology was diminished with the increasing concentration of the plant extract (Figure 1). Contrasted with the control group, the number of surviving cells decreased over incubation time and with increasing AEAML concentrations. This recommends presentation to low concentrations for longer treatment times could result in cytotoxicity comparable to presentation to higher concentrations for shorter treatment times. In this manner, this outcome unmistakably shows that the inhibitory effect of AEAML on Huh-7 cell growth was exerted in a time and concentration dependent manner.

Usually utilized system for the estimation of apoptosis is comet test which is a quick and touchy strategy for the recognition of DNA damage in individual cells, instigated by various genotoxic specialists. In the present study, AEAML prompted DNA damage of Huh-7 cells with expanding length of comet tail were likewise inspected and analyzed by software (Figures 2 and 3). Extremely huge dose dependent DNA damage was observed after treatment of Huh-7 human hepatocellular carcinoma cell lines with AEAML. Aftereffects of this study uncovered that Huh-7 cells demonstrated most astounding comet tail length when these cells were treated with $1.5 \mathrm{mg} / \mathrm{ml}$ AEAML.

To decide the molecular mechanisms of AEAML induced apoptosis in Huh-7 cells, the expression levels of several apoptosis-related genes and proteins were inspected. Results revealed that increasing concentration of AEAML down regulated the anti-apoptotic Bcl-2 gene

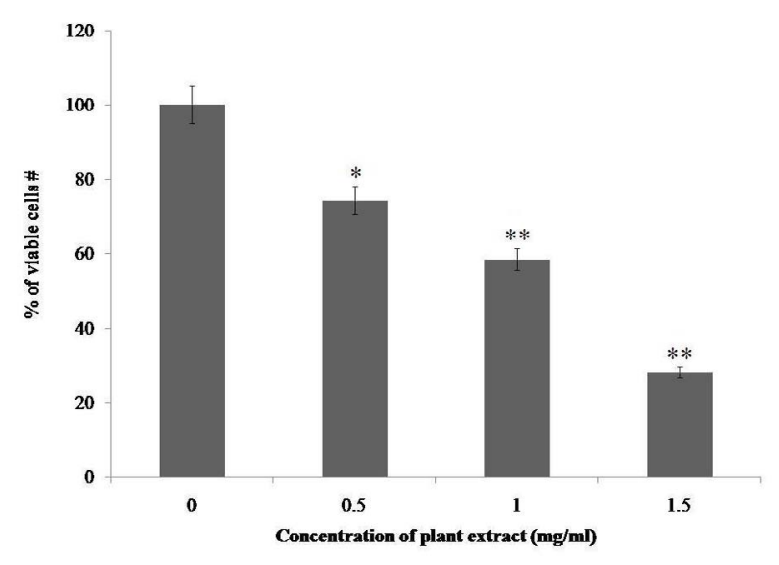

Note: \#Significance based on Kruskal-Wallis test $(P<0.05)$. *Significance based on Mann-Whitney U multiple comparison test: Control vs. $0.5 \mathrm{mg} / \mathrm{ml}$ AEAML $(P<0.05)$, Control vs. $1.0 \mathrm{mg} / \mathrm{ml}$ AEAML $(P<0.01)$, Control vs. 1.5 $\mathrm{mg} / \mathrm{ml}$ AEAML $(\mathrm{P}<0.01)$.

Figure 1: Effect of aqueous extract of Annona muricata leaves (0, 0.5, 1.0 and $1.5 \mathrm{mg} / \mathrm{ml}$ ) on Huh 7 cell line on cell viability assay (MTT assay).

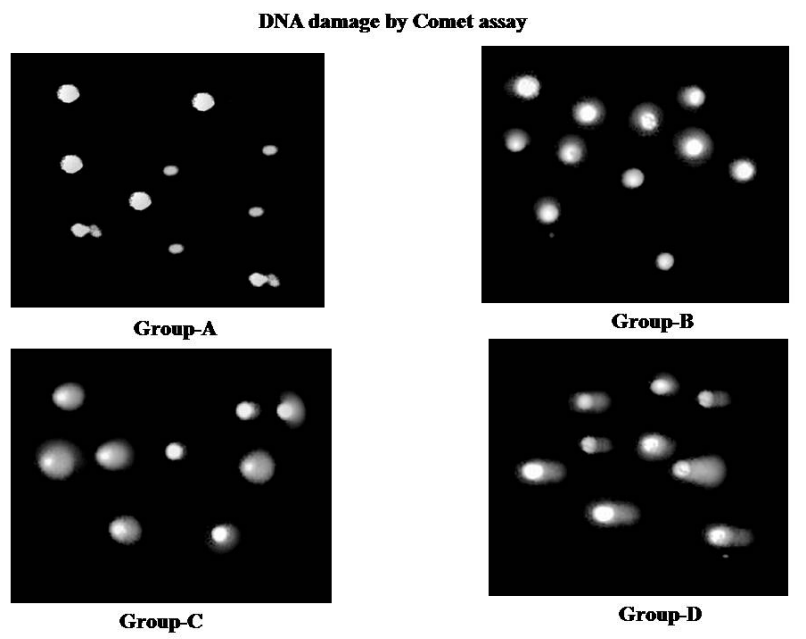

Figure 2: Effect of aqueous extract of Annona muricata leaves on Huh 7 cell line on DNA damage by Comet assay at the doses of $0 \mathrm{mg} / \mathrm{ml}(\mathrm{A}), 0.5 \mathrm{mg} / \mathrm{ml}$ (B), $1.0 \mathrm{mg} / \mathrm{ml}(\mathrm{C})$, and $1.5 \mathrm{mg} / \mathrm{ml}(\mathrm{D})$.

as evidenced by dose dependent decreased mRNA expression (Figure 4). Whereas, dose dependent up regulation of mRNA expression of pro-apoptotic Bax gene (Figure 5) was observed when Huh-7 cells are treated with the increasing concentration of AEAML $(0.5 \mathrm{mg} / \mathrm{ml}, 1.0$ $\mathrm{mg} / \mathrm{ml}$ and $1.5 \mathrm{mg} / \mathrm{ml}$ ). The endogenous control GAPDH gave strong positive bands. Further, the protein expression levels of caspase 3 and caspase 9 were verified by western blotting.

Both, caspase- 3 and caspases- 9 were found to be activated in 


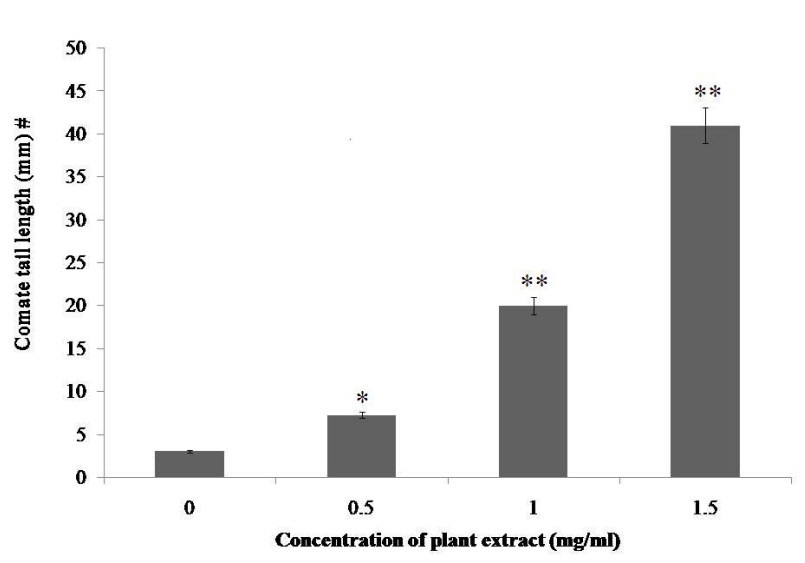

Note: \#Significance based on Kruskal-Wallis test $(P<0.05) .{ }^{*}$ Significance based on Mann-Whitney $U$ multiple comparison test: Control vs. $0.5 \mathrm{mg} / \mathrm{ml}$ AEAML $(P<0.05)$, Control vs. $1.0 \mathrm{mg} / \mathrm{ml}$ AEAML $(P<0.01)$, Control vs. $1.5 \mathrm{mg} / \mathrm{ml}$ AEAML $(\mathrm{P}<0.01)$.

Figure 3: Effect of aqueous extract of Annona muricata leaves $(0,0.5,1.0$ and $1.5 \mathrm{mg} / \mathrm{ml}$ ) on Huh 7 cell line on DNA damage by Comet assay with respective DNA tail length.

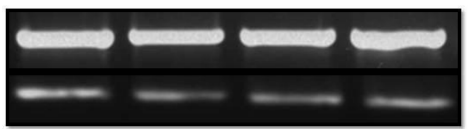

GAPDH

Bcl2

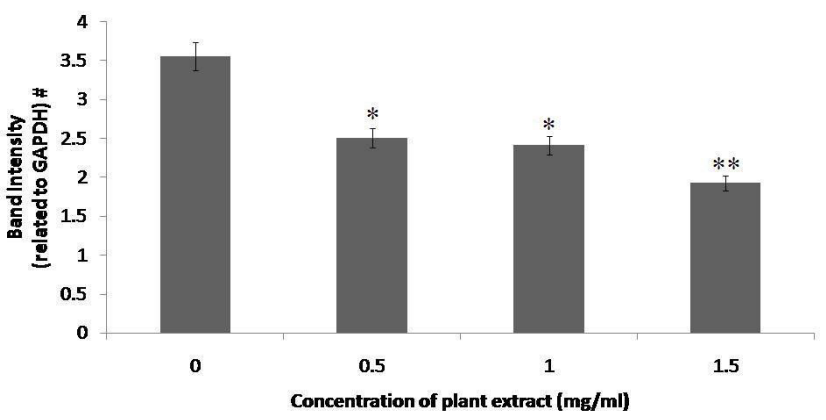

Note: \#Significance based on Kruskal-Wallis test $(\mathrm{P}<0.05)$. ${ }^{*}$ Significance based on Mann-Whitney U multiple comparison test: Control vs $0.5 \mathrm{mg} / \mathrm{ml}$ AEAML $(P<0.05)$, Control vs. $1.0 \mathrm{mg} / \mathrm{ml}$ AEAML $(P<0.05)$, Control vs. $1.5 \mathrm{mg} / \mathrm{ml}$ AEAML $(P<0.01)$.

Figure 4: Effect of aqueous extract of Annona muricata leaves (0, 0.5, 1.0 and $1.5 \mathrm{mg} / \mathrm{ml}$ ) on Huh 7 cell line on mRNA expression level of $\mathrm{Bcl} 2$.

Huh-7 cells when they were treated with AEAML, (Figure 6,7) This activation were also found to be dose dependent as protein expression of caspases- 3 and caspases- 9 were increased consistently with the increasing dose of AEAML $(0.5 \mathrm{mg} / \mathrm{ml}, 1.0 \mathrm{mg} / \mathrm{ml}$ and $1.5 \mathrm{mg} / \mathrm{ml})$.

\section{Discussion}

Now-a-days folk medicines have taken a pivotal role in the treatment of various diseases because of multidrug resistance and other causes. Bioactive compounds present in the plant extract have the potential to be used as medications by providing novel and new products for the prevention and treatment of various diseases. Such medications are now emerging as target for the researchers to find a cure for diseases including various cancers [15].
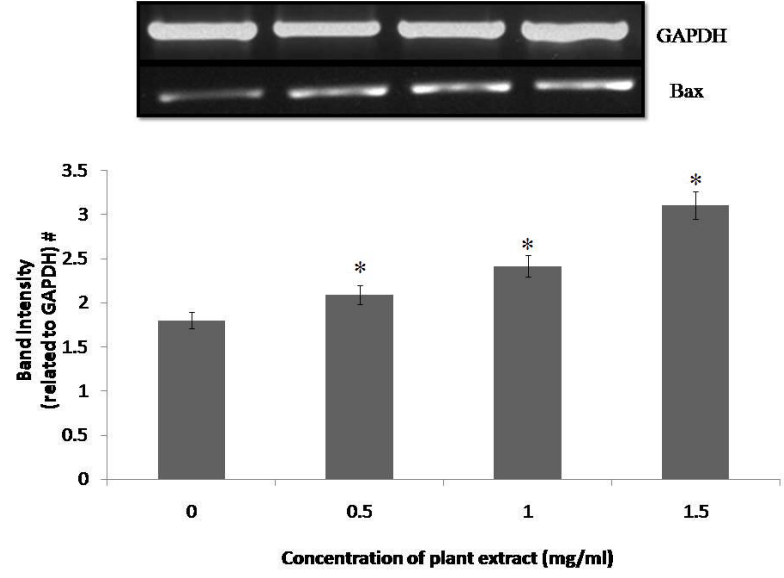

Note: \#Significance based on Kruskal-Wallis test $(P<0.05)$. *Significance based on Mann-Whitney $U$ multiple comparison test: Control vs. $0.5 \mathrm{mg} / \mathrm{ml}$ AEAML $(P<0.05)$, Control vs. $1.0 \mathrm{mg} / \mathrm{ml}$ AEAML $(P<0.05)$, Control vs. $1.5 \mathrm{mg} /$ $\mathrm{ml}$ AEAML $(\mathrm{P}<0.05)$.

Figure 5: Effect of aqueous extract of Annona muricata leaves $(0,0.5,1.0$ and $1.5 \mathrm{mg} / \mathrm{ml}$ ) on Huh 7 cell line on mRNA expression level of Bax.
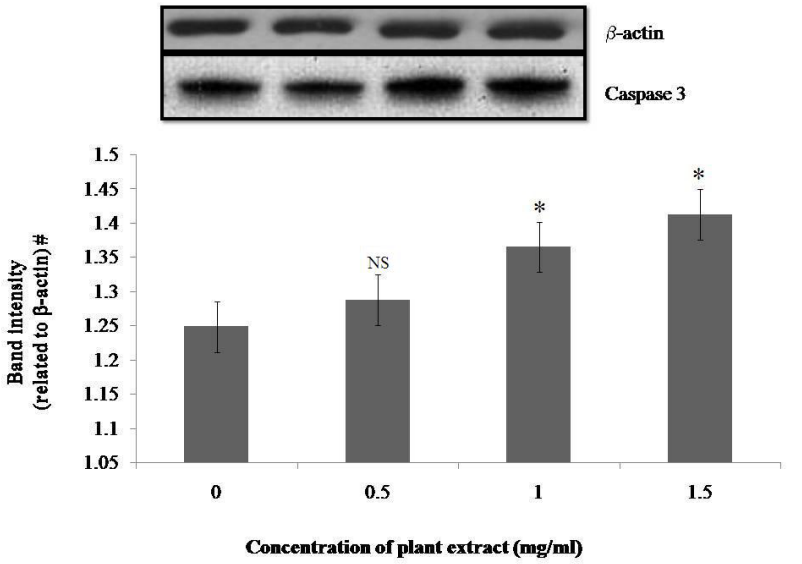

Figure 6: Effect of aqueous extract of Annona muricata leaves $(0,0.5,1.0$ and $1.5 \mathrm{mg} / \mathrm{ml}$ ) on Huh 7 cell line on Western blot of caspase 3. \#Significance based on Kruskal-Wallis test $(P<0.05)$. ${ }^{*}$ Significance based on MannWhitney U multiple comparison test: Control vs $0.5 \mathrm{mg} / \mathrm{ml}$ AEAML (NS: Not significant), Control vs $1.0 \mathrm{mg} / \mathrm{ml} \mathrm{AEAML}(P<0.05)$, Control vs $1.5 \mathrm{mg} / \mathrm{ml}$ AEAML $(P<0.05)$.

The present study portrays the possibility of Annona muricata leaves as a source of anti-cancer drug. The aqueous extract of the leaves was tried for its cytotoxic and apoptotic properties in Huh7 cells in vitro. Earlier studies have reported that Annona muricata leaves extract is selectively toxic against various types of cancerous cells without harming healthy cells [16-18]. Results of MTT assay gives the confirmation of cytotoxic effects of AEAML on the Huh-7 human liver cancer cells in the present study. Percentage cell viability of Huh-7 cell lines was carried out by using Trypan blue dye exclusion technique. At concentration of $0.5 \mathrm{mg} / \mathrm{ml}$ AEAML, the viability of the cells are $74.3 \%$; at concentration of $1 \mathrm{mg} / \mathrm{ml} \mathrm{AEAML}$, the viability of the cells are $58.3 \%$, at concentration of $1.5 \mathrm{mg} / \mathrm{ml}$ AEAML, the viability of the cells are $28 \%$. It suggests that Annona muricata leaves have cytotoxic activity in Huh7 cancer cell lines in a dose dependent manner. 


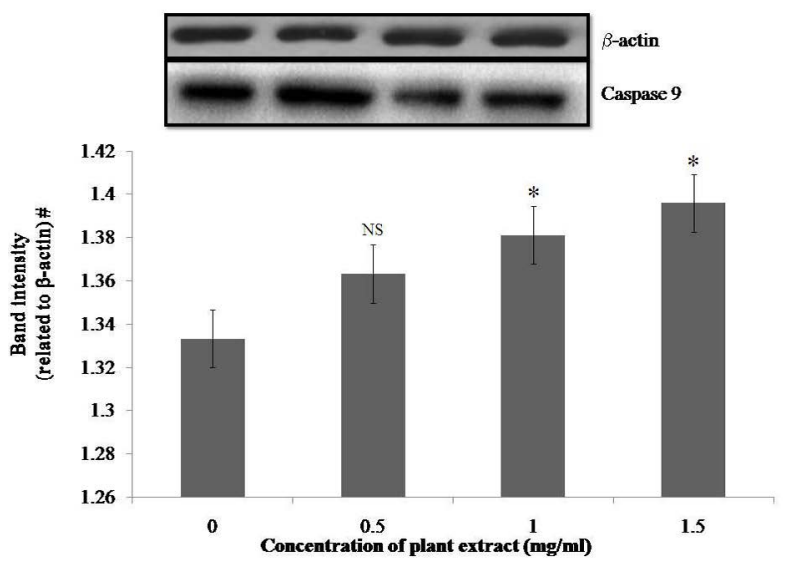

Figure 7: Effect of aqueous extract of Annona muricata leaves $(0,0.5,1.0$ and $1.5 \mathrm{mg} / \mathrm{ml}$ ) on Huh 7 cell line on Western blot of caspase 9. \#Significance based on Kruskal-Wallis test $(\mathrm{P}<0.05)$. ${ }^{*}$ Significance based on MannWhitney $U$ multiple comparison test: Control vs $0.5 \mathrm{mg} / \mathrm{ml}$ AEAML (NS: Not significant), Control vs $1.0 \mathrm{mg} / \mathrm{ml}$ AEAML $(P<0.05)$, Control vs $1.5 \mathrm{mg} / \mathrm{ml}$ AEAML $(P<0.05)$.

Apoptosis assumes a vital role in the cancer prevention. A cell fails to undergo apoptosis by means of mutation or biochemical hindrance, can keep dividing and develop to become a tumor [19]. In this way, we initially chose to test the anti-cancer effects of AEAML by the mechanism of apoptosis in Huh-7 cells. The single cell gel electrophoresis (SCGE) or comet assay combines the simplicity of biochemical techniques for detecting DNA single strand breaks, alkali-labile sites and cross linking with the single cell approach typical of cytogenetic assays of DNA damage. In the present study, treatment of Huh-7 cells with AEAML was resulted in increased comet parameters like tail length, thereby indicating that the level of DNA damage increased in a dose-dependent manner.

$\mathrm{Bcl}-2$ is astounding for imparting its anti-apoptotic role in various cell types. It has been found that $\mathrm{Bcl} 2$ play an important role in resistance of cancer cells to chemotherapy or radiation therapy [20]. Antiapoptotic $\mathrm{Bcl} 2$ is now a prime focus for novel anti-cancer therapeutics as a result of its commitment to cancer development and progression by promoting cell survival. On contrary, Bax is pro-apoptotic in nature and is distributed over many tissues of human body. By and large, Bax can offer apoptotic signal to a cell by forming homodimer. Be that as it may, Bcl-2 forms competing heterodimers with Bax and can inhibit the development of apoptosis [21]. In the present study, the average band intensity of Bcl-2 was lower in Huh-7 cells supplemented with $1.5 \mathrm{mg} / \mathrm{ml}$ AEAML than the cells without supplementation. Conversely, AEAML dose dependently promotes Bax expression in Huh-7 cells. Lopsidedness of molecular mechanisms of proliferation and apoptosis has been found to be associated with the development of hepatocellular cancer, emphasizing the reduction of apoptosis as a major underpinning factor. In the present study, it is evident that AEAML has promoted the Bax upregulation simultaneously with Bcl-2 down regulation in a dosedependent manner in Huh-7 cells. Therefore, these results are well in line with the earlier report that there are upregulation of pro-apoptotic proteins Bax and Bak and down regulation of anti-apoptotic protein $\mathrm{Bcl} 2$ in cell lines undergoing apoptosis [22]. In this way, we speculate that AEAML regulate balance between $\mathrm{Bcl} 2$ and $\mathrm{Bax}$ expression and induces apoptosis in Huh-7 human liver cancer cells in the present study.
Caspases are accounted for to be act as crucial mediators of apoptosis. Among them, caspase- 3 is a frequently activated death protease, catalyzing the specific cleavage of many key cellular proteins. Activation of caspase- 3 may occur by both mitochondrial cytochrome $c$ release and caspase- 9 dependent or independent pathway. To date, two noteworthy groups of caspases have been distinguished and are thought to be involved in apoptosis pathways, including executioners or effectors (caspase-3, -6, -7) and initiators (caspase-2, -8, -9, -10) [23]. Among the executioner caspases, caspase- 3 is considered to be the most critical one which is activated by any of the initiator caspases (caspase-8, caspase-9, or caspase-10) [24]. Further, caspase-3 is accounted for to be indispensable for apoptotic chromatin condensation and DNA fragmentation in all cell types examined [25]. These makes the caspases-3 a significant controller of certain processes associated with the dismantling of the cell and the formation of apoptotic bodies. But, it may also function before or at the stage when commitment to loss of cell viability is made [25]. Impressive proof is there that disruption of mitochondrial functions as evident by loss of trans membrane potential, permeability transition (PT) and release of cytochrome c leading to impaired electron transport are considered as the important episode in many apoptotic cell deaths [26]. The release of cytochrome $c$ actuated by a variety of death stimuli results in the activation of a complex of apoptosis-activating factor 1 (Apaf-1) and caspase-9, leading to the cytochrome c-dependent processing of pro-caspase- 3 and apoptosis in a number of scenarios. Intrinsic and extrinsic pathways are activated by their own initiator caspases, namely caspase- 9 and -8 , respectively. The activation of initiator caspases will, in turn, leads to activation of executioner caspases. Caspase- 3 is considered as the most disparaging of killer caspases. The execution pathway leads to cytomorphological changes, namely chromatin condensation, cell shrinkage, formation of apoptotic bodies followed by phagocytosis of the apoptotic cell [27]. In the present study, we researched whether different concentrations of aqueous extract of Annona muricata can activate the caspases in Huh-7 human liver cancer cells. The activity of both caspase- 9 and caspase-3 were fundamentally lifted when Huh-7 cells were treated with $0.5 \mathrm{mg} / \mathrm{ml}, 1.0 \mathrm{mg} / \mathrm{ml}$ and $1.5 \mathrm{mg} / \mathrm{ml}$ of AEAML, suggesting that the plant extract has induced apoptosis predominantly via mitochondrial-mediated intrinsic pathway. The western blot analysis of caspases likewise demonstrated that the protein expression of cleaved caspase-3 and -9 were dose-dependently increased upon treatment with the AEAML. In the present study, the caspase 3 and caspase 9 expressions were increased significantly in Huh-7 cells treated with graded increasing doses of the aqueous extract of Annona muricata. This result suggests the involvement of caspase cascade in aqueous extract of Annona muricata mediated apoptosis in Huh-7 cells.

Taking everything into account, results of this study demonstrate that the extract of Annona muricata leaves possess good potential for use as cancer chemotherapeutic agent. Furthermore, our data indicate that the aqueous extract of Annona muricata leaves specifically reduce viability of hepatocellular carcinoma cell lines possibly through G0/G1 or S phase arrest or possibly via induction of sub-G0/G1 DNA fragmentation. Be that as it may, the mechanism of the action is still pending. Along these lines, further investigation of the molecular mechanism(s) involved is needed to fully understand the use of Annona muricata as a chemopreventive food.

\section{Acknowledgement}

Mr. Gaurab Banerjee, Mr. Abhishek Kantha and Ms. Manali Dholey of Department of Physiology, Serampore College is gratefully acknowledged for the technical help during this study.

\section{Conflict of Interest}

Authors have no conflict of interests to declare. 
Citation: Banerjee A, Sengupta A, Maji B, Nandi A, Pal S, et al. (2017) Possible Cytotoxic Activity of Annona muricata Leaves in Huh-7 Human Liver Cancer Cells. Hepatol Pancreat Sci 1: 104.

Page 6 of 6

\section{References}

1. Xua HS, Wuc YW, Xud SF, X Suna HX, Chend FY, et al. (2009) Antitumor and immunomodulatory activity of polysaccharides from the roots of Actinidia eriantha. J Ethnopharmacol 125: 310-317.

2. Malcolm RA (2005) Liver stem cells: Implications for hepatocarcinogenesis. Stem Cell Rev 3: 253-260.

3. Jemal A, Bray F, Center MM, Ferlay J, Ward E, et al. (2011) Global cancer statistics. CA Cancer J Clin 61: 69-90.

4. Minari JB, Okeke U (2014) Chemopreventive effect of Annona muricata on DMBA-induced cell proliferation in the breast tissues of female albino mice. Egyptian J Med Human Gen15: 327-334.

5. Kuno T, Tsukamoto T, Hara A, Tanaka T (2012) Cancer chemoprevention through the induction of apoptosis by natural compounds. J Biophys Chem 3 : 156-173.

6. Moghadamtousi SZ, Fadaeinasab M, Nikzad S, Mohan G, Ali HM, et al. (2015) Annona muricata (Annonaceae): A review of its traditional uses, isolated acetogenins and biological activities. Int J Mol Sci 7: 15625-15658.

7. Liu N, Yang HL, Wang P, Lu YC, Yang YJ, et al. (2016) Functional proteomic analysis revels that the ethanol extract of Annona muricata L. induces liver cancer cell apoptosis through endoplasmic reticulum stress pathway. J Ethnopharmacol 189: 210-217.

8. Hamizah S, Roslida A, Fezah O, Tan KL, Tor YS, et al. (2012) Chemopreventive potential of Annona muricata $\mathrm{L}$ leaves on chemically-induced skin papillomagenesis in mice. Asian Pac J Cancer Prev 13: 2533-2539.

9. Endrini S, Suherman, Widowati W (2014) Annona muricata leaves have strongest cytotoxic activity against breast cancer cells. Universa Medicina 3: 179-184

10. Moghadamtousi SZ, Kadir, Paydar M, Karimian ERH (2014) Annona muricata leaves induced apoptosis in A549 cells through mitochondrial-mediated pathway and involvement of NF-kB. BMC Complement Altern Med 14: 299.

11. Rosdi MNM, Daud NNNM, Zulkifli RM, Ya'akob H (2015) Cytotoxic effect of Annona muricata Linn leaves extract on Capan-1 cells. J Appl Pharmaceutical Sci 5: 45-48.

12. Rachmani EPN, Suhesti TS, Widiastuti R (2012) The breast of anticancer from leaf extract of Annona muricata against cell line in T47D. Int J Appl Sci Tech 2: $157-164$.

13. Suyatmi, Suselo YH, Jus SA (2012) The selective cytotoxicity of ethanolic extract of Annona muricata leaf on HeLa cervical cancer cells. Proceeding of the International Conference: Research and Application on Traditional Complementary and Alternative Medicine in Health Care (TCAM).
14. AwukuAsare G, Afriyie D, Ngala RA, Abutiate H, Doku D, et al. (2014) Antiproliferative activity of aqueous leaf extract of Annona muricata on the Prostate, BPH-1 Cells and some target genes. Integrative Cancer Ther 14: 65-74.

15. Sharmila K, Padma PR (2013) Anticancer activity of Artemisia vulgaris on hepatocellular carcinoma (HepG2) cells. Int J Pharmacy and Pharmaceutical Sci 5: 479-483

16. Rieser MJ, Fang XP, Rupprecht JK, Hui YH, Smith DL, et al. (1993) Bioactive single-ring acetogenins from seed extracts of Annona muricata. Planta Med 59: 91-92.

17. Wu FE, Gu ZM, Zeng L, Zhao GX, Zhang Y, et al. (1995) Two new cytotoxic monotetrahydrofuran annonaceous acetogenins, annomuricins $A$ and $B$, from the leaves of Annona muricata. J Nat Prod 58: 830-836.

18. O'Connor L, Huang DC, O'Reilly LA, Strasser A (2000) Apoptosis and cell division. Curr Opin Cell Biol 12: 257-263.

19. Williams NG, Roberts TM (1994) Signal transduction pathways involving the Raf proto-oncogene. Cancer Metastasis Rev 13: 105-116.

20. Terada T, Nakanuma Y (1996) Expression of apoptosis, proliferating cell nuclea antigen, and apoptosis-related antigens (bcl-2, cmyc, Fas, Lewis(y) and p53) in human cholangiocarcinomas and hepatocellular carcinomas. Pathol Int 46 : 764-770.

21. Naseri MH, Mahdavi M, Davoodi J, Tackallou HS, Goudarzvand M, et al (2015) Up regulation of Bax and down regulation of $\mathrm{Bcl} 2$ during 3-NC mediated apoptosis in human cancer cells. Cancer Cell Int 15: 55.

22. Hill MM, Adrain C, Duriez PJ, Creagh EM, Martin SJ (2004) Analysis of the composition, assembly kinetics and activity of native Apaf-1 apoptosomes. EMBO J 23: 2134-2145

23. Elmore S (2007) Apoptosis: A review of programmed cell death. Toxicol Patho 35: $495-516$.

24. Porter A, Janlcke R (1999) Emerging roles of caspase-3 in apoptosis. Cell Death and Differentiation 6: 99-104.

25. Kluck RM, Martin SJ, Hoffman BM, Zho JS, Green DR, et al. (1997) Cytochrome c activation of CPP32-like proteolysis plays a critical role in a Xenopus cell-free apoptosis system. EMBO J 16: 4639-4649.

26. Delgado ME, Olsson M, Lincoln FA, Zhivotovsky B, Rehm M (2013) Determining the contributions of caspase-2, caspase- 8 and effector caspases tointracellular VDVADase activities during apoptosis initiation and execution. BBA-Mol Cell Res 1833: 2279-2292.

27. Nayaka HB, Londonkar RL, Asha TNK, Sanjeev Kumar CB, Sudarshan M (2014) In vitro cytotoxic and gene toxicity effects of flavonoid of Portulaca Oleracea L on HepG2 and K562 malignant cell lines. Int J Basic and Appl Bio 2: 89-93. 